Die neuen Vererbungsgesetze. By Prof. C. Correns. Pp. viii +75 . (Berlin: Gebrüder Borntraeger.) 2 marks.

Experimental Domestic Science. By R. H. Jones. Pp. ix +235 . (London: W. Heinemann.) 2s. $6 d$.

Matter and Energy. By F. Soddy. Pp. 256. (London: Williams and Norgate.) is. net.

Ueber Vererbung und Rassenhygiene. By Prof. $H$. Bayer. Pp. iv $+50+5$ plates. (Jena: G. Fischer.) 2 marks.

Trattato di Chimica Organica Generale e Applicata all' Industria. By Prof. E. Molinari. Seconda Edizione. Pp. xxiv + ro87. (Milano: U. Hoepli.) I8 lire.

Modern Science and the Illusions of Prof. Bergson. By the Hon. S. R. Elliot. Pp. $x i x+257$. (London: Longmans and Co.) 5s. net.

Cocoa: its Cultivation and Preparation. By W. H. Johnson. Pp. ix + i86. (London: J. Murray.) 5s, net.

The National Physical Laboratory. Collected Researches. Vol. viii., I9I2. Pp. iv $+25 \mathrm{I}+$ plates.

(Teddington: The National Physical Laboratory.)

The National Physical Laboratory. Report for the

Year I9II. Pp. ro3+plates. (Teddington: The National Physical Laboratory.)

For and Against Experiments on Animals.

S. Paget. (London: H. K. Lewis.) 3s. 6d. net.

Handbuch der Pharmakognosie. By A. Tschirch. Lief. 29 and 30. Pp. 641-775+xi. (Leipzig: C. H. Tauchnitz.) Each 2 marks.

\section{DIARY OF SOCIETIES.}

\section{THURSDAY, MAY 2.}

Roval Socretv, at 4.-Election of Fellows.-At 4.30.-Petrifications of the Earliest European Angiosperms : Dr. Marie C. Stopes.-The Distribution of Oxydases in Plants and their rôle in the Formation of Pigments: Dr. F. Keeble and Dr. E. F. Armstrong.--The Manifestation of Active Resistance to the Growth of Implanted Cancer : Dr. B. R. G. Russell. -The Nature of the Immune Reartion to Transplanted Cancer in the Rat: Dr. W. H Woglam.-1)n the Instability of a Cortical Point: T. G. Brown and Prof. C. S. Sherrington, F.R.S -The Measurement of Trypanosoma Prof. C. S. Sherrington, F. R.S - The Measurement of Trypanosoma
rhodesiense: Dr. J. W. W. Stephens and Dr. H. B. Fantham. Royal. Institution, at 3 .- Explorations in the Canadian Rocky MounROYAL. INSTITUTION, at $3 .-$ Exploration
tains: Prof, J. Norman Collie, F.R.S.

LinneAn Societry, at 8.-On the Structure of the Palæozoic seed Lagenostoma ovoides, Will: Miss T. L. Prankerd. - Additions to the Flora of
s. Plactic stoma ovoides, Will: Miss T. L. Prankerd.-Additions to the Flora of
Western and North-Western Australia: Dr. Karl Domin. - Freshwater Western and North.Western Australia : Dr. Karl Domin. - Freshwater
Rhizopoda from the States of New York, New Jersey, and Georgia, Rhizopoda from the States of New York, New Jersey, and Georgia,
U S.A.; with a Supplement on the Collection from the Seychelles: G. H. U S.A.; with a Supplement on the Collection from the Seychelles: G. H. Wailes.-Ligidium hypnorum. a Woodlouse new to Britain: W. M.
Webb.-New Light on the Linnean Herbarium: The General Secretary. Webb.-New Light on the Linnean Herbarium: The General Secretary.
Institution of El.ectrical ENGINeERs, at 8.- Adjourned Discussion: Instrution of EI.ECTRICAL ENGINERRS, at 8.- Adjourned Discussion:
The Causes Preventing the More General Use of Electricity for Domestic Purposes. FRIDAY, MAY
Roval. Institution, at 9.-The Use of Pedigrees: W. C. D. Whetham,
F.R.S.

InSTITUTION of Mechanical ENGINEERS, at $8 .-$ Resumed discrussion :
Tenth Report to the Alloys Research Committee: on the Alloys of Aluminium and Zinc: Prof. J. O. Arnold.

Geologists' Association, at 8.-The fieology of Sunderland and District with special reference to the Whitsuntide Excursion: Dr. D. Woolacott MONDAY, MAY 6.

Society of ENGINEERS, at 7.30.- The Effert of Intermittency in Limiting Electric Traction for City and Suburban Passenger Transport: W. Yorath Lewi

ARISTOTELIAN Societrv, at 8.-Imagery and Memory : Beatrice Edgell. Royal Geographical Society, at 8.30.-United Nigeria: C. L. Temple, C.M.G.

Royal Society of Arts, at 8.-Heavy Oil Engines: Captain H. R. Sankey, K.E.

VICTORIA INSTITUTE, at 4.30.-International Arbitration in the Greek World: Marcus N. Tod.

Society of Chemical. Industry, at 8.-A New Apparatus for the Coking Tests of Cosl: R. Lessing. -A New Method for the Determination of Ferrocyanides: H. E. Williams. - A Drying Oven: Y. H. Coste.-India Rubber as a Protective Colloid: E. W. Lewis and H. Waumsley. TIESDAY, MAY 7

Royal Institution, at 3 -Insect Distribution, with special reference to the British Islands: F. Balfour Browne.

Royal Anthropological Institute, at 8.15.-Geographical Distribution of Certain Primitive Appliances: H. Balfour

Zoological SOCIETY, at 8. 30.-Lantern and Kinematograph Demonstrations of Photographs of Fishes and Aquatic Animals in Natural Illumination: Dr. Francis Ward.-On a Cullection of Fishes made by. Mr. A. Blayney Percival in British East Africa to the East of Lake Baringo: G. A. Boulenger, F.R.S.-Studies in the Fossorial Wasps of the Family Scolidiæ, Sub-families Elidinæ and Anthoboscina: Rowland E. Turner. -Notes on the Spanish Ibex: Abel Chapman.

NO. $22 \mathrm{I} 8$, VOL. 89$]$
RöNTGEN SocıETY, at 8.15.-The Education of the Brain, considered as an Electrical Machine: W. Deane Butcher.

RoYal Society OF ARTS, at 4.30.-Colonial Vine Culture : Alan Burgoyne, WEDNESDAY, MAY 8.

Roval Soclety of Arts, at 8.-British Rule in Nigeria: E. D. Morel. THURSDAY, MAY

Royal Society, at 4.30.-Prohable Papers: On the Variation with Temperature of the Rate of a Chemical (nange, with an Appendix by Prof. W. Esson, F.R.S : Dr. A. Vernon Harcourt, F. R.S.- - Some Phenomena of Sun-spots, and of Terrestrial Magnetism : Dr. C. Chree, F.R.S.-On the in Spectra of the Oxyhydr. gen Flame and Spark: Sir W. N. Hartley, in.Spectra of the Oxyhydr. gen Flame and Spark: Srr W. N. Hartley, F.R.S., and H. W. Moss. The Transformations of the Active Deposit Reflected by Sheets of Matter of Different 'Thicknesses: W. Wilson.

Roval Institution, at 3.-Recent Explorations in the Canadian Rocky Moval InStituTion, at 3.- Recent Exploration
Mountains: Prof. J. Norman Collie, F.R.S.

InSTITUTION OF FLECTRICAL ENGINEERS, at 7.30.-The Behaviour of NSTITUTION OF ELECTRICAL ENGINEERS, at $7.30 .-$ The Behaviour of
D.C. Watt-hour Meters, more especially for Traction Loads: S. W. Melsom and H. Eastland.-Electric Meters on Variable Loads: Prof. D. Robertson.

Royal. Institution, at 9.-The Gaumont Speaking Kinematograph Films: Prof. W. Stirling.

Royal Astronomical Society, at 5

Malacological. Society, at 8.-A Synopsis of the Recent and Tertiary Fresh-water Mollusca of the Californian Province: Harold Hannibal.-On Dosinia lucinalis, Lam., and it Synonyms: A. J. Jukes-Browne, F.R.S. -New Generic Names and New Species of Marine Mollusca: T. Iredale. Physical. Society, at 8.--A Method of Measuring Small Inductances: S. Butterworth.-The Conversion of Starch into Dextrin by X-Rays : H. A Colwell and Dr. S. Russ. - D mons ration of Apparatus for showing the Generation of Electricity by Carbon at High Temperatures: Dr. J. A. Harker and Dr. G. W. C. Kaye. -Calibration of Wave-meters for Radiotelegraphy: Prof. G. W. O. Howe.

Institute of Metals, at 8.30.-The Inner Structure of Simple Metals: Sir J. A. Ewing, K.C.B., F.R.S.

\section{CONTENTS.}

PAGE

Chemical Spectroscopy. By Prof. E. C. C. Baly, F.R.S.

The Constitution of the Silicates. ByDr. C. H. Desch 212 British Vegetation, By A. D. C. . . . . . . . . 212 Recent Botanical Publications. . . . . . . . . . 213

Our Bookshelf

Letters, to the Editor:-

Burdon Sanderson and Vitalism.-Dr. J. S. Haldane, F.R.S.

A Peculiarity in the Shadows Observed during a Partial Eclipse of the Sun.-Edwin Edser .

Halo during the Solar Eclipse of April I7.-Dr. Marie C. Stopes

The Smoke Problem.-Prof. j B. Cohen, F. R. S.; The Reviewer

Remains of Prehistoric Horse in the Stort Basin.Rev. Dr. A Irving . • . • • • • • . .

n Anode Dark Space in the Discharge in Oxygen.-

F. W. Aston . . . . . . . . . . 218

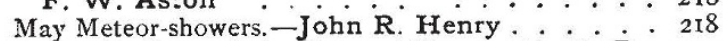
The Solar Eclipse of April 17. (Illustrated.) By Dr.

William J. S. Lockyer . . . . . . . . . . . . 219

Colonial Surveys. By H. G. L. . . . . . . . . . . 222

Notes . . . . . 223

Our Astronomical Column :-

Astronomical Occurrences for May . . . . . . . 227

Cometary Spectra. (Illustrated.). . . . . . . 227

The Spiral Nebulæ . . . . . . . . . . . . 228

Leeds University: New Textile Extension . . . 228

Memoirs of the Geological Survey. By G. A. J. C. 229

Discussions of Climatnlogy . . . . . . . . . . $23^{\circ}$

Bird Notes. By R. L. . . . . . . . . . . . 23 I

University and Educational Intelligence . . . . 232

Societies and Academies . . . . . . . . . . . . 233

Books Received .. . . . . . . . . . . . . . . 235

Diary of Societies . . . . . . . . . . . . 236

Chemistry in its Relation to Manufacture. By G. T. M.

Flowers and their Insect Guests

Cosmogonies, Old and New . . . . . . . . . . . vi

Tannins, Dyes, and Colours. By C. S. . . . . . . vii

Cytological Problems. By J B. F. . . . . . . . viii

An American Manual of Farm Livestock. By

Dr. Francis H. A Marshall

Technology and Literature. By R. S. B. . . . . . ${ }^{\mathrm{x}}$ iii

iv

i

$\mathrm{x}$ 